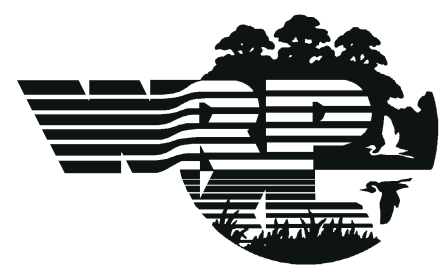

\title{
Salt Marsh Planting: Example Contract Specifications
}

PURPOSE: This technical note provides an example set of contract specifications that can be used as a template by Corps personnel for planting salt marsh vegetation. While the example presented here will be useful to U.S. Army Corps of Engineers biologists, engineers, or contracting officers preparing their own contract specifications, it is not intended to substitute for knowledge regarding appropriate planting techniques and an understanding of wetland restoration principles.

BACKGROUND: There are numerous examples of restored and created coastal marshes in the United States. Smooth cordgrass (Spartina alterniflora), saltmeadow cordgrass (Spartina patens), glasswort (Salicornia virginica), saltwort (Batis maritima), and other species have all been successfully established by planting. This technical note is based on actual salt marsh planting contract specifications used for various projects within the Galveston, Mobile, and Norfolk Districts. Because every project has specific and unique requirements, the example presented here should be used only as a guide. Also, because this technical note was written with intertidal marshes in mind, issues such as herbivore predation and unfavorable hydrology, which may complicate freshwater marsh establishment, have not been addressed.

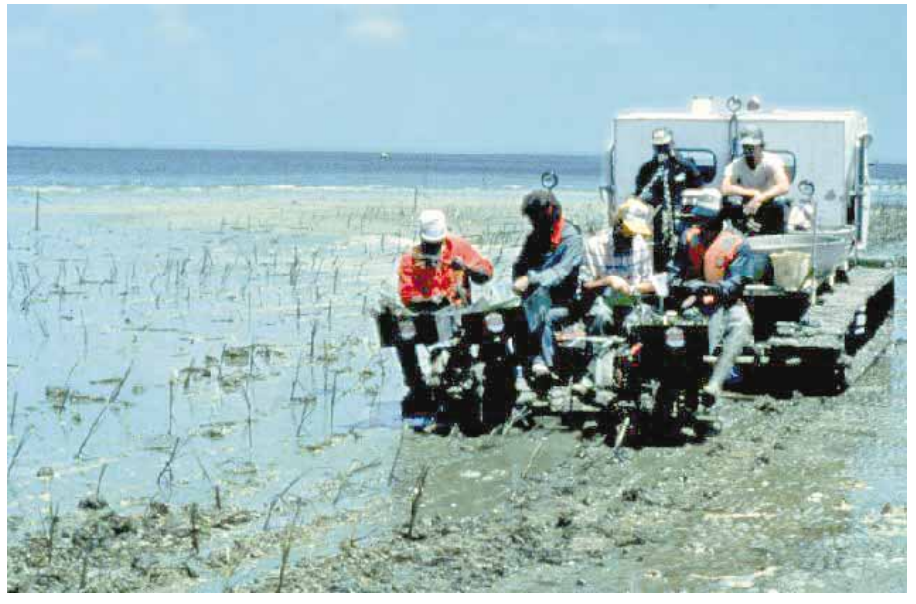

Marsh planting: Effective contract specifications are necessary for successful marsh planting operations

INTRODUCTION: The key to successful contracting is planning. Each project has unique characteristics that must be considered when preparing contract specifications. Also, the physical and biological requirements of the target plant species must be understood and the project site must be compatible with these requirements.

To ensure the best conditions for plant establishment and site stability, a number of factors must be considered, including optimum planting season, plant density, plant source (nursery grown, harvested from adjacent borrow areas, or seeds), whether the site must be graded to achieve the desired elevations, whether soil amendments are needed, and whether protective measures such as fences or breakwaters are necessary. For more information on technical aspects of marsh planting, a number of good references are available, including Lewis (1982); Dunne, Rodrigo, and Samanns (1998); Knutson, Allen, and Webb (1990); and Hayes et al. (in preparation). Along with technical matters, provisions describing administrative matters (such as completion schedule, progress 
reports, and method of payment) must be addressed. All of these factors must be translated into contract plans and specifications.

Caution should be taken not to include too many diverse types of work in a single contract. For example, if a protective levee, fencing, grading, and/or breakwater construction are necessary, it may be wise to contract for these site preparation tasks separately from the actual planting. Care should also be taken to make contract specifications concise and explicit.

Because salt marsh planting is a labor-intensive effort, the usual procurement vehicle is a service contract. This contracting method procures a service based on the specification of a fixed effort (number of acres to be planted) at a fixed price (dollars/acre). Other associated work, such as fencing or grading, would similarly qualify as a service. Service contracts are a competitive form of procurement with the contract generally being awarded to the contractor that can provide the "best value." Best value is determined by taking into account such evaluation factors as prior experience, facilities, equipment, manpower, availability, price, etc. Other types of contracts, such as a Request for Proposals, may also be appropriate depending on the complexity of the work and the need for specialized expertise. District procurement offices should be consulted often during preparation of contracts.

Effective contract management requires frequent meetings with the contractor, preferably on site, to ensure an understanding of all aspects of the contract. Inspection of the work site during the life of the contract is essential. Deficiencies should be reported, corrected, and documented.

In the example that comprises the remainder of this technical note, text boxes with explanatory notes accompany subsections of the example contract specifications.

ACKNOWLEDGMENTS: The authors would like to express appreciation to the following Corps employees who provided information and or materials for this technical note:

$$
\begin{aligned}
& \text { Joyce Williams, CEMVK-ED-D } \\
& \text { Laura Cespedes, CEMVK-ED-A } \\
& \text { Mike Smart, CEERD-ES-P } \\
& \text { Mark Hudgins, CENAO-EN-EH } \\
& \text { Gail Stewart, CESWG-EC-ES } \\
& \text { Hollis Allen, CEERD-EN-S }
\end{aligned}
$$

\author{
Ruth Ladd, CENAE-CO-R \\ Steven M. Martin, CENAO-CO-R \\ Susan Rees, CESAM-PD-EC \\ John Reddoch, CEMVN \\ Michael Sheenan, CENAE-CO-R
}

POINTS OF CONTACT: For additional information, contact Ms. Carolyn Schneider (601-6343222,schneic@wes.army.mil),Dr. Bill Streever(601-634-2942, streevw@wes.army.mil), or Mr. Rick Medina (409-766-3065, richard.medina@swg02.usace.army.mil), or the manager of the Characterization and Restoration of Wetlands Research Program, Dr. Russell F. Theriot (601-6342733,therior@wes.army.mil). This technical note should be cited as follows:

Schneider, C. B., Streever, W., and Medina, R. (2000). "Salt marsh planting: Example contract specifications," WRP Technical Notes Collection (ERDC TN-WRP-WG-RS3.4), U.S. Army Engineer Research and Development Center, Vicksburg, MS. www.wes.army.mil/el/wrp 


\section{REFERENCES}

Construction Specifications Institute. (1995). "MasterFormat: Master list of numbers and titles for the construction industry." Construction Specification Institute, Alexandria, VA.

Dunne, K. P., Rodrigo, A. M., and Samanns, E. (1998). "Engineering specification guidelines for wetland plant establishment and subgrade preparation," Technical Report WRP-RE-19, U.S. Army Engineer Waterways Experiment Station, Vicksburg, MS.

Hayes, D. F., Olin, T. J., Fischenich, J. C., and Palermo, M. R., compilers. "Wetlands Engineering Handbook," in preparation, U.S. Army Engineer Research and Development Center, Vicksburg, MS.

Knutson, P. L., Allen, H. H., and Webb, J. W. (1990). “Guidelines for vegetation erosion control on wave-impacted coastal dredged material sites," Technical Report D-90-13, U.S. Army Engineer Waterways Experiment Station, Vicksburg, MS.

Lewis, R. R. (1982). Creation and restoration of coastal plant communities. CRC Press, Inc., Boca Raton, FL.

U.S. Army Corps of Engineers. (1993). "Engineering and design-plans and specifications for Civil Works projects," Engineer Regulation 1110-2-1200, Washington, DC.

U.S. Army Corps of Engineers. (1998). “Engineering and design-specifications,” Engineer Regulation 1110-1-8155, Washington, DC.

NOTE: The contents of this technical note are not to be used for advertising, publication, or promotional purposes. Citation of trade names does not constitute an official endorsement or approval of the use of such products. 


\section{EXAMPLE CONTRACT SPECIFICATIONS ${ }^{1}$}

\section{PROJECT TITLE \\ SECTION 02900 \\ MARSH VEGETATION PLANTINGS}

\section{PART 1 GENERAL}

\subsection{REFERENCES}

The publications listed below form a part of this specification to the extent referenced. Publications are referred to in the text by basic designation only.

American Society for Testing and Materials (ASTM)

ASTM D 50341995 Breaking Strength and Elongation of Textile Fabrics (Grab Test)

ASTM D 50351995 Breaking Strength and Elongation of Textile Fabrics (Strip

Method)

Comments: ASTM has developed standards that are useful if using fabric mats for soil stabilization/erosion control purposes or pre-planted fabric mats. Those ASTM standards that are referred to in the text of the actual contract specifications should be included in the "REFERENCES" subsection. For the purposes of this example, two potentially relevant references have been listed.

\subsection{SYSTEM DESCRIPTION}

The work covered by this section includes: a) provision of all plant, labor, equipment, and materials; and b) performance of all operations in connection with the planting of salt marsh vegetation in the area shown in the attached drawings ${ }^{3}$ and as directed by the Contracting Officer or his authorized representative.

1 All engineering and design specifications for Corps projects must be prepared in accordance with ER 1110-2-1200 and ER 1110-1-8155. All Corps offices are required to use SPECSINTACT to prepare construction specifications (HQUSACE memorandum - 14 April 1997).

2 This number refers to the MasterFormat section entitled "Planting" (Construction Specifications Institute 1995). If applicable, the last two digits of this section number may be changed to reflect a more specific subsection as described in Section 02900 ("Planting") of MasterFormat.

3 "Attached drawings" are referred to throughout this technical note. In an actual contract, scale drawings showing site location and other information would be included as part of the contract, but these drawings are not included here. 


\subsection{SUBMITTALS}

Government approval is required for submittals with a "GA" designation. Submittals designated "FIO" are for information only. The following shall be submitted in accordance with Section 01330 SUBMITTAL PROCEDURES.

SD-01 Data ${ }^{1}$

Comments: The "submittals" section of the contract provides details about documentation required as part of the project. Use of the designations "GA" and "FIO" varies from District to District and may have as much to do with past failures and successes with various contractors as with District policy. If there is any question as to the suitability of the items to be submitted, a "GA" designation might be in order for most or all submittals.

Comments: If the Corps Contracting Officer believes that there is a need for information about various aspects of the project, that information can be requested as part of the data subsection. CEGS defines "Data" as "submittals which provide calculations, descriptions, or documentation regarding the work."

Equipment; FIO

A list and/or description of equipment used for the planting operation.

\section{SD-08 Statements}

\section{Delivery; FIO}

Delivery Schedule for equipment, plants, and soil amendments.
Comments: The statements subsection allows the Contracting Officer to request information about how the project will be accomplished. CEGS defines "statements" as "a document, required of the Contractor, or through the Contractor, from a supplier, installer, manufacturer, or other lower tier Contractor, the purpose of which is to confirm the quality or orderly progression of a portion of the work by documenting procedures, acceptability of methods or personnel, qualifications, or other verifications of quality."

1 The "SD" numbering system comes from the Submittal Procedure, Section 01330 of the Corps of Engineers Guide Specifications for Construction (CEGS - Sep 1997). SD stands for submittal description. Standard descriptions of 10 possible categories of submittals used by the Corps can be found in CEGS 01330. However, in an effort to standardize submittal requirements among Federal agencies, a new set of submittal designations will be provided to the Army, Navy, and NASA in late 1999 or early 2000. For an update on the new SD designations, go to TECHINFO on the Internet at:

http://www.hnd.usace.army.mil/techinfo/index.htm. 


\section{SD-13 Certificates}

Marsh plants; GA

Fiber mats; GA

Soil Amendments; FIO

Fertilizers

Prior to the delivery of material, certificates of compliance shall be submitted certifying that materials meet the specified requirements. Where such certification requires a laboratory test, the test shall be certified and reported as part of the certificate of compliance. Testing shall be performed by an approved independent laboratory within 30 days of submittal of reports. Certified copies of the reports shall be provided for the following:

a. Marsh plants. Cultivar name, genetic purity, and location of collection for transplanted stock.

b. Fertilizers. Manufacturer's chemical analysis and application instructions.

c. Sandy soil. Particle size/gradation, chemical and mechanical analyses.

Comments: The addition of sandy soil would only be necessary in the case of highly organic, poorly drained soils that do not allow for the diffusion of $\mathrm{O}_{2}$ and $\mathrm{CO}_{2}$ into and out of the sediment. Other soil amendments, such as lime or organic matter, may be needed in other circumstances.

\section{SD-14 Samples}

Natural fiber mats for planting; GA

Wooden stakes for anchoring fiber mats; GA Natural fiber twine for mat tie-downs; GA
Comments: The Corps Contracting Officer may want to inspect materials to be used in the project. CEGS defines "Samples" as “...physical examples of materials, products, and units of work as complete units or as portions of units of work." 


\section{SD-18 Records}

Maintenance; FIO

Maintenance work

performed, area

repaired or reinstalled, diagnosis for unsatis-

factory stand of plants.

\subsection{SOURCE INSPECTION}

The sources of marsh vegetation and delivered sandy soil shall be subject to inspection.
Comments: Here, the Corps Contracting Officer can ask for records documenting compliance with various contract requirements. CEGS defines "Records" as "documentation to record compliance with technical or administrative requirements."

\subsection{DELIVERY, INSPECTION, STORAGE, AND HANDLING}

\subsubsection{Soil amendments}

Soil amendments shall be delivered to the site in the original, unopened containers bearing the manufacturer's name and guaranteed chemical analysis of the container contents. If amendments are furnished in bulk, a certificate from the manufacturer indicating the above information shall accompany each delivery.

\subsubsection{Marsh Plants}

Plants shall be protected from exposure to wind and direct sunlight during delivery to prevent desiccation, internal heat buildup, or contamination (see "Storage" paragraph below).

\subsubsection{Inspection}

Plants shall be inspected by the Contracting Officer or his authorized representative upon arrival at the job site for conformity to cultivar, genetic purity, and quality requirements. Unacceptable materials (e.g., desiccated, diseased, insect-infested, lack of root biomass) shall be removed from the job site at no additional cost to the government.

\subsubsection{Storage}

Plants shall be stored in designated areas and covered with moist burlap, straw, or other covering. Covering shall allow air to circulate preventing internal heat from building up. Plants shall be protected from exposure to wind and direct sunlight until installed. 


\subsubsection{Handling}

Plants shall not be damaged during handling. Except for bulk deliveries, material shall not be dropped or dumped from vehicles.

\subsubsection{Time Limitations}

Plants shall be installed within 24 hr of delivery if possible, or if not installed on the day of delivery, all

Comments: The allowable length of time between delivery and planting will vary for different projects, but in general plants should be installed within one day of delivery. stock shall be covered in straw, moist burlap, or other material, as approved by the Contracting Officer, until the time of installation, which shall be no longer than 3 days under any circumstances.

Comments: If the planting site size is too large for this time restriction, staged shipments and subsequent planting can be specified here. 


\section{PART 2 PRODUCTS}

\subsection{MARSH VEGETATION}

\subsubsection{Species}

10,000 sprigs of Spartina alterniflora, 0' - 1' NAVD83 (North American

Vertical Datum, 1983) 10,000 sprigs of Juncus roemerianus, 1' - 2' NAVD83

5,000 sprigs of Spartina patens above 2' NAVD83

Comments: Species to be planted and planting elevations will vary depending on the coastal region, desired wetland functions, and other factors. Tidal amplitude and the duration of inundation must also be taken into account. Number of sprigs will be determined by project size, wave and wind energy conditions (erosion potential), and distance between plants (see paragraph 2.2).

\subsubsection{Quality}

All plants shall be living and healthy with vigorous root systems suitable to ensure establishment of the plant. Marsh plants shall be nursery grown under climatic conditions similar to those in the locality of the project. Plants may be 2-in. or larger plugs, bare root or 2-in. pots. Bare-root plants shall have stem and root development similar to 2-in. plugs. All plants shall be free from material detrimental to a healthy stand of plants. Any plants exposed to excessive heat or drying shall be rejected.

Comments: Throughout this example, the source of plants is assumed to be nursery stock. If using donor sites (borrow areas) as the source of plants, a number of items will need to be included concerning the donor site. For example:

- The necessary approvals must be obtained from landowners and regulatory agencies.

- The Contractor shall take care not to denude any area of marsh or otherwise cause long-term damage to the borrow area.

- The transplants shall be obtained by removing only one clump of the desired vegetation per square yard of marsh surface using a shovel or other suitable implement.

- The root structure shall be carefully maintained intact during removal, transport, and planting. 


\subsection{FIBER MATS, STAKES, TWINE}

a. Fiber mats for marsh planting shall be wetland geotextile mats specifically manufactured for soil stabilization/erosion control purposes. They shall be made of 100-percent biodegradable fiber that maintains tensile strength in alternating dry, wet, and frozen conditions, and even when submerged. The Contractor shall submit a minimum 1- $\mathrm{ft}^{2}$ sample in accordance with the "SUBMITTALS" paragraph.

$b$. Preplanted fiber mats for marsh planting shall be wetland geotextile mats specifically manufactured for this purpose. They shall be made of 100-percent biodegradable fiber with a thickness adequate to withstand wave impacts and fluctuating tide levels found at the site. The Contractor shall submit a minimum $1-\mathrm{ft}^{2}$ sample in accordance with the "SUBMITTALS" paragraph.

c. Anchor stakes shall be pressure- treated soft wood such as pine or spruce, about $1-1 / 2$ in. by $1-1 / 2$ in. by 24 in. ( $3.8 \mathrm{~cm}$ by $3.8 \mathrm{~cm}$ by $61 \mathrm{~cm}$ ). Stakes shall be notched about 6 in. $(15 \mathrm{~cm})$ from the top to accept heavy twine tie-downs. The Contractor shall submit a sample stake in accordance with the "SUBMITTALS" paragraph.

d. Twine for fiber mat tie-downs shall be natural fiber such as standard bailing twine. The Contractor shall submit a sample in accordance with the "SUBMITTALS" paragraph.

Comments: Wedge-shaped stakes (sometimes called "dead-stout"), 2 in. by 4 in. by $24 \mathrm{in}$. ( $5 \mathrm{~cm}$ by $10 \mathrm{~cm}$ by $61 \mathrm{~cm})$, may be used. Also, longer stakes may be required in deeper water or where there is soft sediment (e.g., dredged material).
Comments: More durable coir twine (derived from coconut husks) may be preferred here.

\subsection{SUBSTITUTIONS}

Substitutions will not be allowed without written request and approval from the Contracting Officer. 


\section{PART 3 EXECUTION}

\subsection{INSTALLATION}

\subsubsection{Planting Time}

Preferable dates for the establishment of marsh plants are between 1 March and 1 September. However, fall or winter planting is acceptable if the ground is in a satisfactory condition for planting.
Comments: The appropriate time frame for planting will vary with location, climate, and species to be planted. Also, some flexibility in timing should be allowed due to unexpected weather conditions that may arise, such as late or early freezes, excessive rain or drought, storms, etc.

\subsubsection{Installation Methods}

a. The Contractor shall define areas for planting of each species using stakes and string lines. Staked areas shall be approved by the Contracting Officer or his representative prior to planting.

b. Marsh plants shall be placed in the soil at previous growing depth, with one sprig per hole. Potted plants shall be planted to top surface of potting medium.

Comments: Dunne, Rodrigo, and Samanns (1998) suggest a planting depth 1-2 in. deeper than the nursery or source location. One sprig per hole may be adequate in low- energy conditions (see Knutson, Allen, and Webb (1990)). If the decision is made to plant more than one sprig per planting hole, be sure to make note of it in the contract specs so that there will be no confusion in estimates of quantity. In the specifications, any indication of quantity should refer to the total number of sprigs required for the project, not the number of planting holes.

c. The Contractor shall smooth out any high or low areas prior to planting so that the area to be planted slopes upward from 0 NAVD to the high edge of the sand fill.

Comments: Where this contract calls for a smooth planting surface, other projects might better reflect "natural" marsh conditions if some degree of topographic variability is designed into the landscape. Contract specifications should reflect desired topography. As noted in Dunne, Rodrigo, and Samanns (1998), if the project involves grading, channel excavation, or any activity that would restrict daily tidal flows, care must be taken to prevent hypersaline soil conditions. Where flows are restricted, frequent soil testing may be required, especially immediately prior to any planting program.

d. The Contractor may use any one of the following planting methods: 
METHOD No. 1: Fiber mats shall be placed over the area to be planted and anchored with wooden stakes at 3 -ft spacing along the edge of the mats and in a staggered pattern throughout the remainder of the mat at the same spacing (see details on drawings). The mats shall be further held in place by heavy twine tied between stakes at mat level. Edges of the mat should be keyed into the substrate to prevent scour from waves beneath the mat. Plugs shall be placed into the sand through 8 -in. slits cut into the mats 18 in. apart in a staggered pattern as shown on the drawing.

Comments: Spacing requirements may vary from project to project. Spacing decisions should be based on the species, and cover requirements (if any) for a given time frame.

METHOD No. 2: Similar to METHOD No. 1, except plants are preplanted into a thicker fiber mat by the mat supplier prior to installation.

METHOD No. 3: Plant rolls are constructed by laying a 10-ft length of 3-ft-wide burlap on the ground and filling with sandy soil previously placed at the site. Plants are placed in this soil at 18-in. spacing and the burlap edges are brought together and fastened with metal rings at 8 -in. spacing to form a roll about $9 \mathrm{ft}$ long and 8 to $10 \mathrm{in}$. round. Rolls are placed end to end into trenches made in the sandy soil so that the top of the roll is approximately level with the top of the trench. Plant roll runs shall be spaced at 18-in. intervals, placed parallel to the shoreline, and proximate to wave action. See details on drawings.

Comments: In this example, fiber mats are required for all three of the method options. However, sprigging directly into the substrate also works well at many sites, and seeding has been successful at some sites (see Dunne, Rodrigo, and Samanns (1998)). Knutsen, Allen, and Webb (1990) describe plant rolls similar to those suggested in METHOD No. 3.

\subsubsection{Fertilization}

Simultaneous with the planting, each plant shall be fertilized as follows:

\subsubsection{Spring and Summer Planting}

Fertilize each plant with 30 grams of 3- to 4-month slow-release fertilizer $(18 \mathrm{~N}-6 \mathrm{P}-12 \mathrm{~K})$.
Comments: Dunne, Rodrigo, and Samanns (1998) recommend a 20-10-5 nutrient mix for fertilizers used during planting and a 20-10-10 nutrient mix for postplanting fertilizers. However, many sites do not seem to benefit from fertilization. 


\subsubsection{Fall and Winter Planting}

Fertilize each plant with 30 grams of 8- to 9-month slow-release fertilizer (18N-6P-12K).

\subsection{MAINTENANCE}

a. Planting maintenance shall continue for 1 year after completion of the work. During this period, any dead plants shall be replaced. Any washouts or eroded areas shall be repaired and replanted. All trash and debris washed or blown into the planted area shall be immediately removed and the area shall be protected from foot and vehicle traffic.

Comments: It may be unreasonable to expect the Contractor to keep the area free of all debris if the area to be planted is in or near an area of high human activity. The same may also be true of areas where there is a high probability of invasion by exotic species (see next comment box). It is possible that inclusion of these restrictions may greatly increase the cost of the project or eliminate prospective bidders.

b. A record of each site visit shall be furnished describing the maintenance work performed, areas repaired or reinstalled, and diagnosis of reasons for unsatisfactory stand of marsh vegetation.

Comments: There may be a need to include in the contract specifications a requirement for monitoring of invasion by exotic or nuisance plant species such as Phragmites australis (common reed), which in certain conditions may have a competitive advantage over desired species. 


\subsection{PLANT ESTABLISHMENT PERIOD}

The establishment period will be in effect for 12 months at no additional cost to the government. All plants that die during the establishment period shall be replaced. No additional plant establishment period will be required for replacement plants.

Comments: Dunne, Rodrigo, and Samanns (1998) suggest that, unlike the contract specifications for "traditional landscaping" where a 1-year plant establishment period is the norm, for salt marsh vegetation there usually is no plant establishment period unless the Contractor is (a) using undersized stock, (b) planting outside the specified planting window, or (c) extending the height or duration of natural flood events beyond the design conditions of the project. In those cases, Dunne, Rodrigo, and Samanns (1998) suggest that the Contracting Officer institute a 1-year guarantee with a 50-percent survival (including vegetative off-shoots) or 40-percent coverage requirement. Other requirements are possible. For example, a commitment to canopy closure, some other percent survival (100 percent, 75 percent, etc.), or a higher percentage of coverage might be required. The values used must be attainable and meaningful, e.g., "40 percent average cover in 30 randomly placed $1-\mathrm{m}^{2}$ quadrats by the middle of the second growing season." 